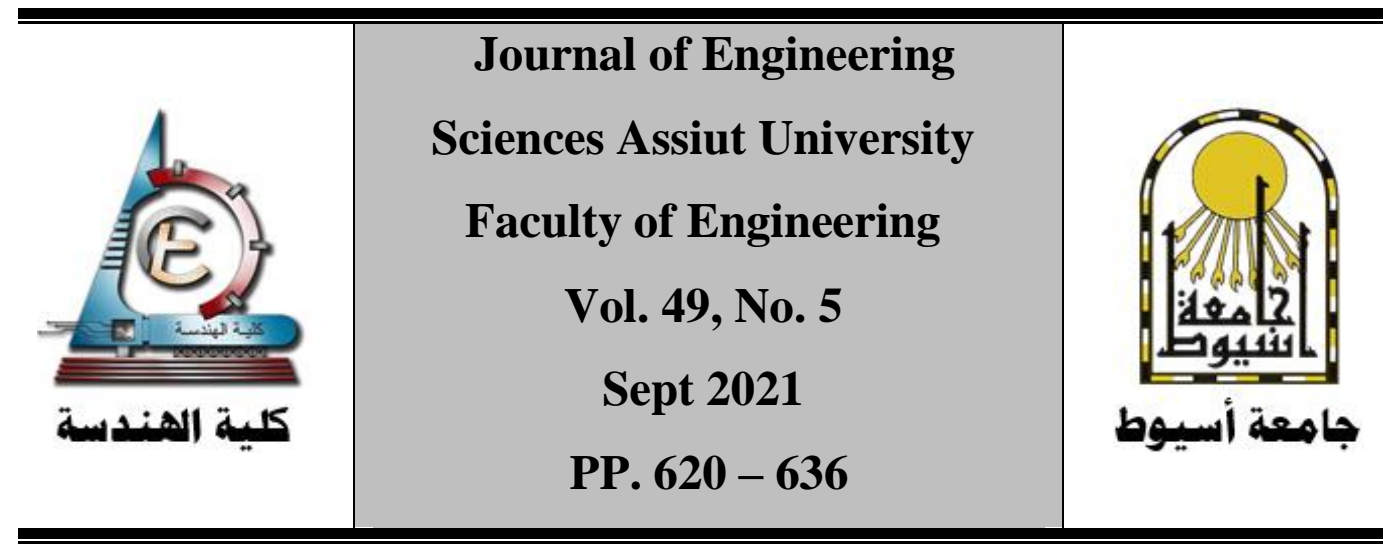

\title{
THE PREFERENTIAL COMMINUTION OF BINARY MIXTURES
}

\author{
Sherein Ahmed M.E. Rizk
}

Faculty of Engineering, Beni-suef University

E-Mail: shereinahmedrizk2020@gmail.com

Received 9 March2021; Revised 30 June 2021; Accepted 4 July 2021

\begin{abstract}
Representative samples of limestone, ilmenite, and quartz, were dry batch ground separately and in binary mixtures of limestone-ilmenite and limestonequartz in different compositions in the ball mill. The study aimed to investigate the effect of the feed mixture composition on the mill product characteristics as reflected on each of the two components. The results indicated that quartz affects as a tough, hard component more than the ilmenite as a heavy component on the grindability of limestone in their mixtures. Such behavior may be attributed to the ability of quartz to transfer the kinetic energy of the grinding media to limestone component more than ilmenite, which increases the preferential comminution of limestone by quartz more than that by ilmenite.
\end{abstract}

KEYWORDS: grindability, comminution of binary mixtures, Grinding of heterogeneous materials, physical and mechanical properties of rocks 


\section{Introduction}

The comminution process as an important unit operation is widely applied in industries such as mineral processing, ceramics, cement, and chemical industries. Ball mills have been the most common equipment used for the comminution of ores in mineral industries because of their flexibility and versatility in reducing minerals to smaller sizes [1-3].

Most raw materials come from multiphase heterogeneous rocks that contain the target mineral. To free the target minerals, the rock should be comminuted to fine enough sizes [4]. The grinding behavior of solids is complex due to the effect of some or all of their mechanical properties, and the picture becomes even more complicated for such heterogeneous materials [5]. In the comminution of heterogeneous materials, an understanding of how the different constituents interact with each other may prove useful for optimizing the operation [6]. The particulates that exhibit heterogeneous breakage characteristics have been considered as a mixture of two individual components. Each component has its own breakage parameters, which are constant within each matrix [7]. Since the grinding environment in an industrial mill is never homogeneous, the next logical step would be to study the comminution kinetics of heterogeneous systems being ground in the tumbling mills. Heterogeneity in feed constituents can be presented by the presence of two minerals with different physical properties in the mill feed, or differences in the size distribution of the feed constituents. Hence, the study of mixture grinding can be classified into two categories [2], one in which the grinding of a mixture of a single size fraction of two minerals with different physical properties [8-10], and the other category in which a coarse size fraction is ground with fine particles of the same mineral $[2,8]$. Studies on the grinding kinetics of mixtures of two minerals with different physical properties have been performed wet by Zhao et al [8] and dry by Kapur and Fuerstenau [9]. Kapur and Fuerstenau studied the energetics and kinetics of mixture grinding by using the energy split factor. They found that this concept was highly useful for analyzing different aspects of mixture grinding. Two physically dissimilar materials were ground separately and in admixture in a ball mill by Rose and Matsumura [10]. They deduced an expression that relates the grinding times necessary for specified feed materials when the materials were ground separately or in a mixture. Fuerstenau 
and Venkataraman [11] showed that calcite was ground faster when ground in the presence of hard quartz than if it was ground alone. Similarly, in a simultaneous grinding, Kanda et al [12] found that the grindability of limestone was higher when it was ground in a mixture than when it was ground separately. A model which makes possible complete distribution composition prediction has been developed by Barbery and Leroux [13]. This model predicts the composition distribution for particles obtained by breakage multiphase materials. Ipek et al [14] confirmed that if a mixture of three materials of similar density is being ground in a ball mill, the size distribution of the mixture product may be predicted if the grindability characteristics of the individual materials, their mass fractions in the mixture, and the total grinding energy input are known.

Fuerstenau et al [2] ground a coarse fraction $(-1.651+1.168) \mu \mathrm{m}$ of quartz, dolomite, and limestone in the presence of fine fractions (-147 $\mu \mathrm{m})$ of the same materials. It was found that the three material systems, ground in a ball mill, behave similarly i.e., the breakage distribution functions were independent on the mill environment and the breakage rates were increased with decreasing the ratios of coarse to fine. Tavares and Kallemback [15] found that the accumulation of hard components in the mill was increased with decreasing the ratio of Bond work index values of the individual soft and hard components and with increasing the circulating load ratios. Wang [16] stated that understanding the role of texture and crack propagation can provide fundamental knowledge for predicting and improving the energy efficiency of comminution. The results of his study demonstrated that mineral distribution and minerals with lower tensile strength play a very important role in the breakage process. Xie et al [17] studied the breakage of heterogeneous coal and pyrite and coal and calcite. For mixtures of coal and pyrite, the fineness of pyrite progeny was higher than that from individual breakage. Instead, the coal in the mixture showed the opposite trend.

In this study, limestone-ilmenite and limestone-quartz binary mixtures were ground in a ball mill at different mixing feed ratios to illustrate the behavior of each component in the ground mixtures. 


\section{1 - Experimental Work}

\subsection{Materials}

Representative samples of Assiut limestone, Abu-Ghalga ilmenite, and El-Barramyia tough Quartz, were used in this study. These rocks represent soft, heavy, and tough hard materials respectively. A narrow size range $(-4+2 \mathrm{~mm})$ from each rock was prepared carefully by screening process after the primary and secondary crushing steps. These samples were ground separately and as admixtures of $(80 \%+20 \%)$, $(60 \%+40 \%),(40 \%+60 \%)$, and $(20 \%+80 \%)$ of limestone- ilmenite as well as limestone-quartz binary mixtures in a ball mill.

\subsection{Some Physical and Mechanical Properties of Rocks}

The compressive strength of each rock was obtained using the universal compression test machine shown in Fig. (1). The toughness of each studied rock, which is defined as the external work done to overcome the bonding force between crystals to fracture it, was determined by the area under the load-deformation curve [18-21]. Fig. (2) illustrates the load deformation diagram for a limestone specimen as an example and the toughness of the three studied rocks was listed in Table (1).

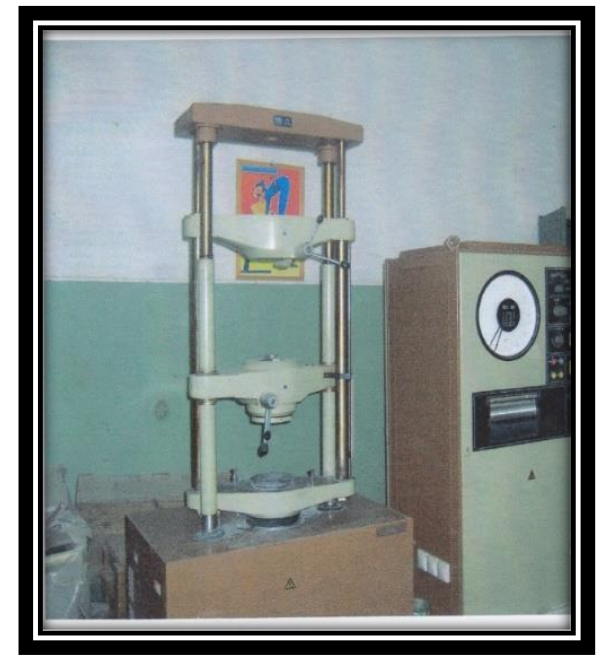

Fig. (1) Universal compression test machine 


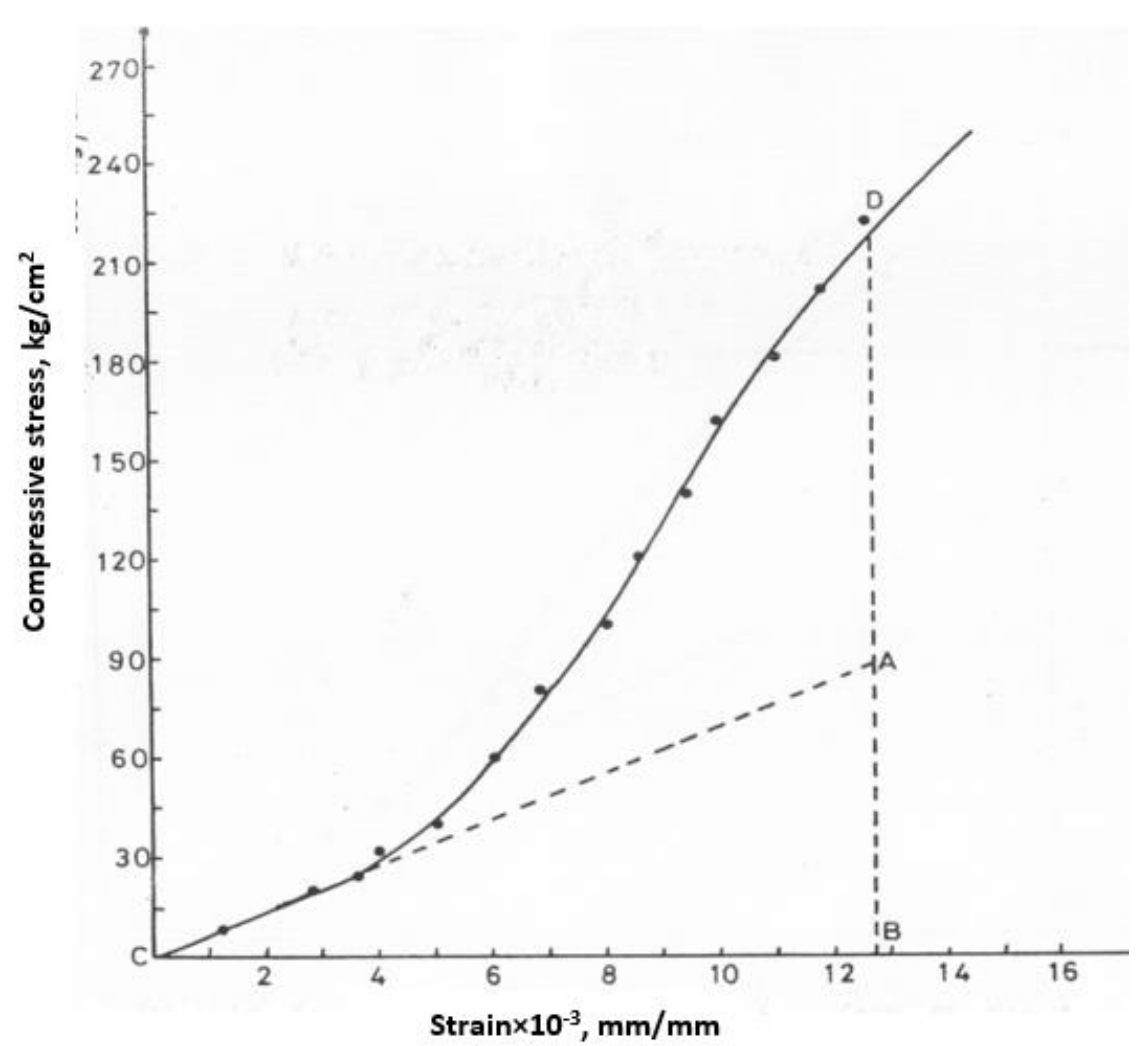

Fig (2). Stress strain diagram for a limestone specimen.

Regarding the hardness test, three specimens of the different studied rocks of dimensions $10 \times 10 \times 2 \mathrm{~cm}$ each were polished and prepared for testing. The surface of each specimen was divided by grids to 16 spots. The hardness was measured at these spots by the Rockwell testing machine shown in Fig. (3). A preliminary load (p0) that is equal to 10 $\mathrm{kg}$, and an additional load (p) that is equal to $52.5 \mathrm{~kg}$., for soft rock (limestone) and $140 \mathrm{~kg}$ for hard rocks (ilmenite, and quartz) were applied as shown in Fig. (4). The penetrator of the machine consisted of a diamond cone with edges of $120^{\circ}( \pm 2)$. The Rockwell-C-Hardness was expressed by Eq. (1) [22].

$$
\mathrm{HRC}=100-\mathrm{e} / 0.002
$$

Where: $\mathrm{e}$ is the remaining depth of indentation after the additional load has been removed. 
Results were contoured to show the variation of the hardness number on the whole area of the specimen. Then, the mean HRC was calculated for each specimen.

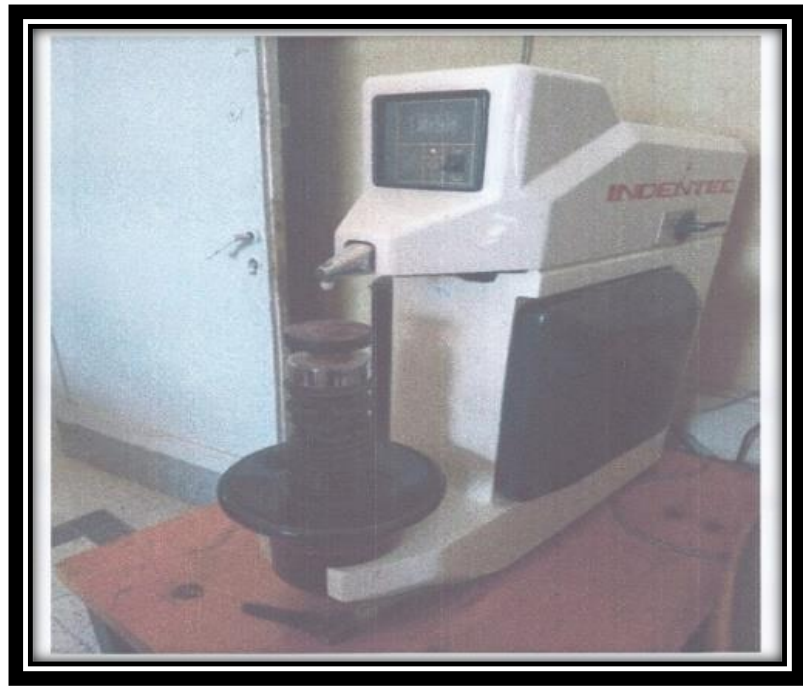

Fig. (3) Rockwell testing machine

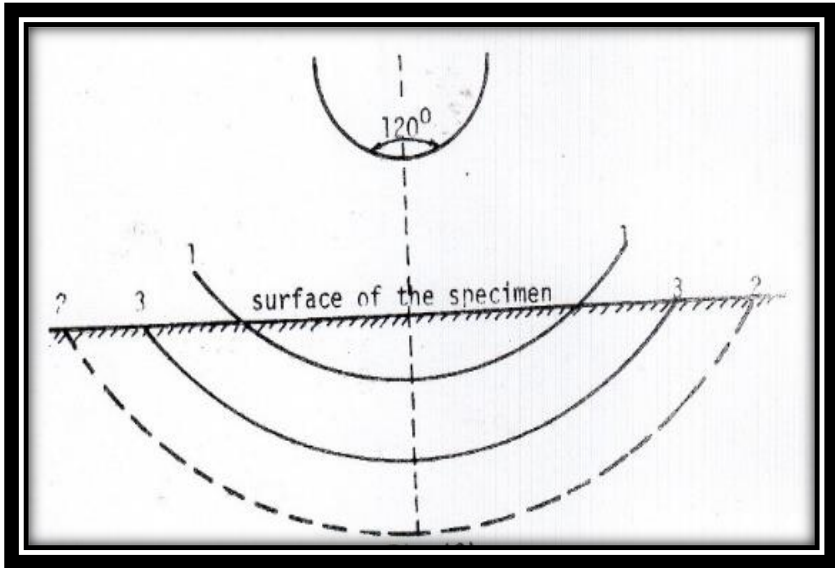

Fig. (4) Diamond cone, angle $120^{\circ}$

1-1 Penetration of cone under preliminary load $\left(\mathrm{p}_{0}\right)$

2-2 Penetration of cone under total load $\left(p+p_{0}\right)$

3-3 Penetration of cone after removal of the additional load $p$, under preliminary load

Referring to the abrasion test, four cubic test specimens of $6 \mathrm{~cm}$ sides were cut from bulk samples of the different studied rocks. The specimens were carefully surface - finished to obtain parallel and 
smooth faces, then worn down under a predicted pressure $(1 \mathrm{~kg} / \mathrm{cm} 2)$ on a rotating cast iron grinding track of prescribed hardness. An abrasive substance (fine sand of $-0.63+0.50 \mathrm{~mm}$ ) was continuously fed under the test specimens. The test specimens were fixed in the holder of the machine shown in Fig. (5) and slowly rotated during the test in order to ensure their uniform wear. As soon as the abrasive disc has made a certain number of revolutions (1000 revolutions at a rate of 28-30 rpm), the machine was automatically stopped. The abrasion value was appointed as a ratio of loss in weight to the original weight of the specimen under the conditions mentioned above.

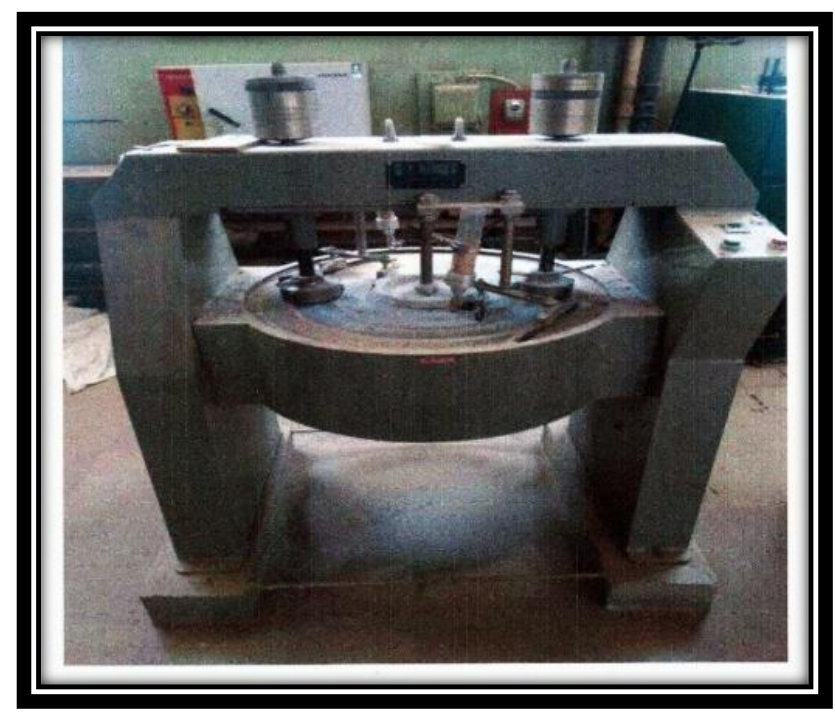

Fig. (5) Abrasion test machine

The measured physical and mechanical properties of the studied rocks were listed in Table (1).

Table (1) Some physical and mechanical properties of the studied rocks.

\begin{tabular}{|c|c|c|c|c|c|c|}
\hline $\begin{array}{c}\text { Rock } \\
\text { name }\end{array}$ & $\begin{array}{c}\text { Compressive } \\
\text { strength, } \\
\left(\mathrm{kg} / \mathrm{cm}^{2}\right)\end{array}$ & $\begin{array}{c}\text { Toughness } \\
\left(\mathrm{cm}^{2}\right)\end{array}$ & $\begin{array}{c}\text { Rockwell } \\
\text { Hardness } \\
(\text { HRC })\end{array}$ & $\begin{array}{c}\text { Abrasion } \\
\text { value } \\
\text { as a ratio }\end{array}$ & $\begin{array}{c}\text { True } \\
\text { density } \\
\left(\mathrm{g} / \mathrm{cm}^{3}\right)\end{array}$ & $\begin{array}{c}\text { Apparent } \\
\text { density } \\
\left(\mathrm{g} / \mathrm{cm}^{3}\right)\end{array}$ \\
\hline $\begin{array}{c}\text { Limestone } \\
\text { Ilmenite }\end{array}$ & 216.6 & 60.8 & 3.2 & 0.206 & 2.27 & 1.11 \\
Quartz & 630.70 & 100.3 & 3.8 & 0.014 & 4.50 & 1.76 \\
\hline
\end{tabular}




\section{Grinding Apparatus and Procedures}

A laboratory scale ball mill of $14 \mathrm{~cm}$ in length and $16 \mathrm{~cm}$ internal diameter was used in dry batch grinding of these samples of rocks and their mixtures. The operating parameters were kept constant as follows: Feed particle size : $-4+2 \mathrm{~mm}$ (closed size range)

Volume of the mill occupied with the balls charge : 55\% of the total mill volume.

\section{The Balls charge consisted of:}

$3.2 \mathrm{~kg}$ steel balls of $2.5 \mathrm{~cm}$ diameter.

$3.2 \mathrm{~kg}$ steel balls of $2 \mathrm{~cm}$ diameter.

$1.6 \mathrm{~kg}$ steel balls of $1.5 \mathrm{~cm}$ diameter.

Mill speed

Grinding time
$: 80 \mathrm{rpm}=75 \%$ of its critical speed.

$: 10$ minutes for all grinding tests.

The volume of voids between balls charge was measured by the displacement with water to be $700 \mathrm{~cm} 3.90 \%$ of this volume $(630 \mathrm{~cm} 3)$ was filled with material, as the grinding operation was dry, which corresponded to $700 \mathrm{~g}$ of limestone, $1111 \mathrm{~g}$ of ilmenite, and $813 \mathrm{~g}$ of quartz. Consequently, the bulk density of the used closed-size range ($4+2 \mathrm{~mm}$ ) of each studied rock was calculated and listed in Table (1). The true density of each studied rock was appointed by using the density bottle. Weights of mixtures components were calculated and listed in Table (2)

Table (2) Weights of feed mixtures components at the different mixing ratio of feed.

\begin{tabular}{|c|c|c|c|c|c|}
\hline \multirow{2}{*}{\multicolumn{2}{|c|}{ Feed mixture components }} & \multicolumn{2}{|c|}{ limestone-Ilmenite mixture } & \multicolumn{2}{|c|}{ limestone-Quartz mixture } \\
\hline & & \multirow{2}{*}{$\begin{array}{l}\text { limestone } \\
(\mathrm{g})\end{array}$} & \multirow{2}{*}{$\begin{array}{l}\text { Ilmenite } \\
\text { (g) }\end{array}$} & \multirow{2}{*}{$\begin{array}{c}\text { limestone } \\
(\mathrm{g})\end{array}$} & \multirow[b]{2}{*}{$\begin{array}{l}\text { Quartz } \\
\text { (g) }\end{array}$} \\
\hline $\begin{array}{c}\text { Limestone } \\
(\%)\end{array}$ & $\begin{array}{c}\text { Ilmenite or } \\
\text { quartz } \%\end{array}$ & & & & \\
\hline 100 & 0 & 700 & 0 & 700 & 0 \\
\hline 80 & 20 & 560 & 222.2 & 560 & 162.6 \\
\hline 60 & 40 & 420 & 444.4 & 420 & 325.2 \\
\hline 40 & 60 & 280 & 666.6 & 280 & 487.8 \\
\hline 20 & 80 & 140 & 888.8 & 140 & 650.4 \\
\hline 0 & 100 & 0 & 111.0 & 0 & 813.0 \\
\hline
\end{tabular}

Each ground sample was mixed thoroughly and three representative samples of it were analyzed by sieving with a screen set from $3.15 \mathrm{~mm}$ to $0.063 \mathrm{~mm}$ using a vibrating sieve shaker. 
Three representative samples, each weighing $5 \mathrm{~g}$ of $-200 \mu \mathrm{m}$ from each ground sample of the mixture were dissolved for leaching out the limestone with diluted hydrochloric acid with water $(50 \% \mathrm{HCL}+50 \%$ water) and the remaining ilmenite or quartz was weighed after filtration and drying. It was assured that the fine fraction $(-200 \mu \mathrm{m})$ of ilmenite or quartz did not react chemically with the dilute acid, which indicated that they did not contain any traces of limestone.

\section{Results and Discussions:}

Table (3) summarizes the results whereas Table (A.1) in Appendix I list the screen analyses of the separately ground samples of limestone, ilmenite, and quartz, respectively. The reduction ratio was calculated by dividing the median size of the feed $(3000 \mu \mathrm{m})$ by the median size of the ground sample, where the median size of the ground sample was calculated as Eq. (2) [23].

Where: $\mathrm{D}=$ the mean size fraction, $\mu \mathrm{m}$,

$$
\text { Median size of ground sample }=\frac{\boldsymbol{\Sigma} \boldsymbol{D} \times \boldsymbol{W}_{\boldsymbol{i}}}{\boldsymbol{\Sigma} \boldsymbol{W}_{\boldsymbol{i}}}
$$

$\mathrm{Wi}=$ weight percent retained, $\%$,

$\Sigma \mathrm{Wi}=100$

From Table (3) limestone has the highest reduction ratio and quartz has the smallest one, while ilmenite has the in-between value. This behavior may be due to the low values of toughness as well as the hardness of limestone, while quartz has high toughness and hardness as seen in Table (1). Table (A.2) (Appendix I) represents the mean particle size analyses of the ground limestone-ilmenite mixture at different percentages of ilmenite. From this table, it is clear that the reduction ratio decreases as the percentage of ilmenite increases in the feed. Table (A.3) (Appendix I) illustrates similar results regarding the limestone-quartz mixture. Table (3) concludes the final results of the ground mixtures. The achieved limestone $\%$ in the fine portion $(-200 \mu \mathrm{m})$ of each ground mixture was calculated as Eq. (3) [24].

$$
\text { Limestone } \%=\frac{\% \text { of fine part in the product } \times \% \text { of limestone in it }}{\% \text { of limestone in the feed }}
$$


Fig (6) represents the effect of the blending ratio of the feed on the reduction ratio of the ground mixtures. This figure show that the reduction ratio decreases as the percentage of ilmenite or quartz increases in the mixture because of increasing of the heavy or tough component (either ilmenite or quartz). It is also seen that the reduction ratio of limestone-ilmenite mixture is higher than that of limestonequartz mixture due to the difference in their hardness and toughness. Fig (7) illustrates the effect of feed blending ratio on the achieved limestone in limestone-ilmenite and limestone-quartz mixtures. From this figure, at any mixing ratio, the size of limestone achieved by grinding with quartz is higher than that achieved by grinding with ilmenite. This behavior may be due to the fact of quartz as a hard tougher component that transfers the kinetic energy of the grinding media to the limestone more than ilmenite as a heavy component. This finding agrees with that predicted by Fuerstenau et al [2], Kanda et al [12], and Gupta [25].

Table (3) Reduction ratios and achieved limestone in the fine portion $(-200 \mu \mathrm{m})$ of the ground limestone-ilmenite and limestone-quartz mixtures

\begin{tabular}{|c|c|c|c|c|c|c|c|c|}
\hline \multicolumn{5}{|c|}{ Limestone-ilmenite mixture } & \multicolumn{4}{|c|}{ Limestone-Quartz mixture } \\
\hline 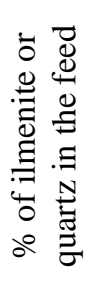 & 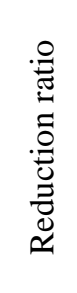 & 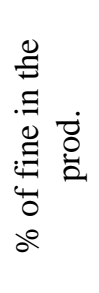 & 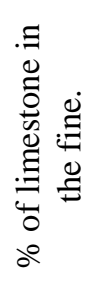 & 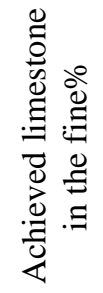 & 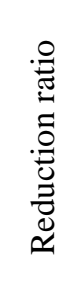 & 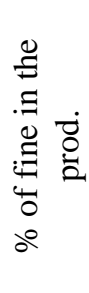 & 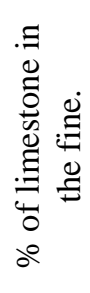 & 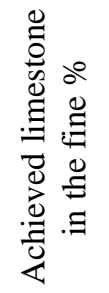 \\
\hline 0 & 6.87 & - & - & - & 6.87 & - & - & - \\
\hline 20 & 4.41 & 48.43 & 70.26 & $42.53^{*}$ & 3.20 & 40.51 & 96.62 & $48.93^{* *}$ \\
\hline 40 & 3.23 & 36.34 & 65.32 & 39.56 & 2.33 & 29.78 & 85.02 & 42.20 \\
\hline 60 & 2.69 & 28 & 48.36 & 33.85 & 2.13 & 24.91 & 59.52 & 37.07 \\
\hline 80 & 1.93 & 14.1 & 42.14 & 29.71 & 1.81 & 12.27 & 54.81 & 33.63 \\
\hline 100 & 2.58 & - & - & - & 1.44 & - & - & - \\
\hline
\end{tabular}




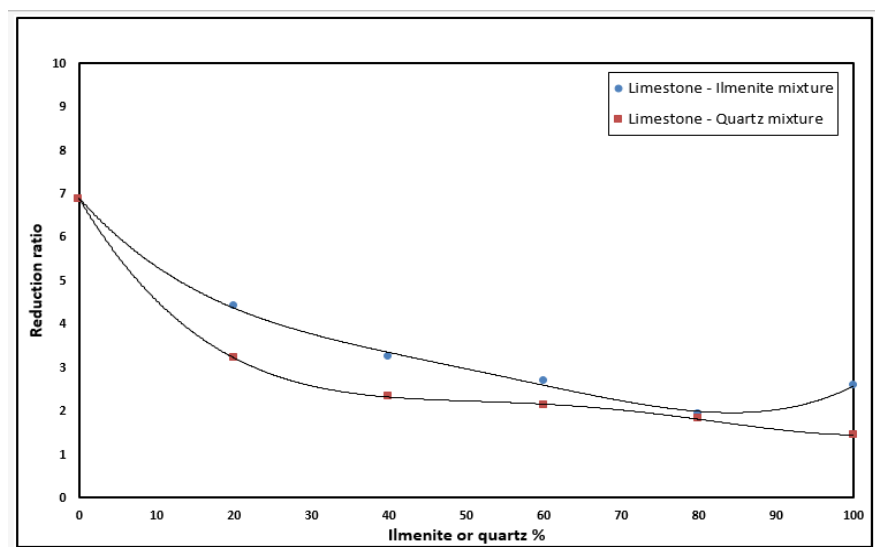

Fig (6): Effect of ilmenite or quartz\% in the feed on the reduction ratio of limestone -ilmenite and limestone - quartz mixtures

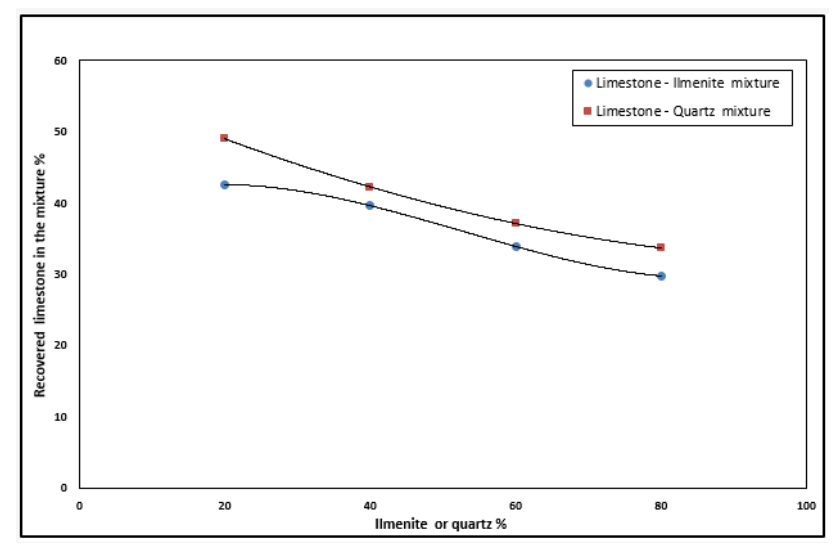

Fig (7): Effect of ilmenite or quartz\% in the feed on the percentage of achieved limestone $\%$ in the fine product $(-200 \mu \mathrm{m})$ of the limestone-ilmenite and limestonequartz mixtures.

\section{Conclusion and Recommendations}

From the results of this investigation and their discussions, it can be concluded that:

- Toughness has a very important effect on the preferential comminution of binary mixtures.

- The percentage of the achieved limestone in the fine of the ground limestone-quartz binary mixture is higher than that of limestone-ilmenite one as quartz is tougher and harder than ilmenite. 
- Mineral particles with high toughness act as energy transfer agents to increase the grinding of soft mineral particles in their mixed feed.

- It is recommended to execute the idea of this work by using the breakage rate function to make the results clearer.

\section{Acknowledgment:}

The author expresses her sincere thanks and gratitude to the authority of Mining and Metallurgical Engineering Department, Assiut University for their help and encouragement through performing the experimental part of this study. Special thanks are to the Dean of the faculty as well as the head of the department.

\section{References}

[1] Gwiranai, D., Daine, H., David, G., and Clayton, B., "Application of basic process modeling in investigating the breakage behavior of UG2 ore in wet milling", Powder Technol.279 (2015) 42-48.

[2] Fuerstenau, D.W., Phatak, P.B., Kapur, P.C., and Abouzeid, A-Z.M., "Simulation of the grinding of coarse/fine (heterogeneous) systems in a ball mill", Int. J. Miner. Process. 99 (2011) 32-38.

[3] Chimwani, N., Glasser, D., Hildebrandt, D., Metzger, M.J. and Mulenga, F.K., "Determination of the mill parameters of a platinum group minerals ore to optimize product size distribution for flotation purposes", Miner. Eng, 43-44 (2013) 67-78.

[4] Meloy, T.P. and Gotoh, K., "Liberation in a homogeneous two-phase ore", Int. J. Miner. Process. 14, (1985) 45-55.

[5] Rizk, A.M.E, and Ahmed, A.A., "Determination of the work index of some Egyptian ores", Bull. of the Faculty of Engng., Assiut University, Vol.23, No.2, July (1995), pp.241-246.

[6] Remenyi, K., "The theory of grinding and the comminution of binary mixtures", Akademiai Kiado, Bodapest, Hungry, (1974).

[7] Rizk, A.M.E., "The influence of the feed particle sizes on the preferential comminution of binary mixture", Al-Azhar Engineering Second International Conference, Vol. IX Mining Engng., December 21-24, (1991), pp.111-118.

[8] Zhao, R., Han, Y., He, M., and Li, Y., "Grinding kinetics of quartz and chlorite in wet ball milling", Powder Technol. 305 (2017) 418-425.

[9] Kapur, P.C, and Fuerstenau, D.W., Energy split in multicomponent grinding", Int.J. Miner. Process. 24 (1988), pp.125-142.

[10] Rose, M.E., and Matsumura, s., "Simultaneous grinding of two materials in a batch ball mill", Trans. Instn Min.Metall. (sect, c: Mineral process. Extr. Metall.), 94 (1985), C40-C46. 
[11] Fuerstenau, D.W. and Venkataraman, "The comminution of multi component feeds under batch and locked-cycle conditions", Int. J. Miner. Process. 22 (1988) 105-118.

[12] Kanda, Y., Abe, Y., and Sasaki, H., "An examination of ultra-fine grinding by preferential grinding", Powder Technol. 56 (1988) 143-148.

[13] Barbery, G. and Leroux, D., "Prediction of particle composition distribution after fragmentation of heterogeneous materials", Int. J. Miner. Process. 22 (1988) 9-24.

[14] Ipek, H., Ucbas, Y., and Hosten, C., "Ternary-mixture grinding of ceramic raw materials", Miner. Eng., 18 (2005) 45-49.

[15] Tavares, L.M., and Kallemback, R.D.C., "Grindability of binary ore blends in ball mills", Miner. Eng. 41 (2013) 115-120.

[16] Wang, Y., "Numerical modeling of heterogeneous rock breakage behavior based on texture images", Miner. Eng. 74 (2015) 130-141.

[17] WeiningXie, Yaqun He, Yong Huang, Hong Li, Shuai Wang, and Biaoli, "Experimental investigation of breakage and energy consumption characteristics of mixtures of different components in vertical spindle pulverizer", Fuel 190 (2017) 208-220.

[18] Marin, J., "Mechanical behavior of engineering materials", Prentic - Hall of India LTD, New Delhi, (1966).

[19] Kabil, Y. and El-Beshlawy, W., "Strength and testing of engineering materials", Mondiale Press, Cairo, (1968).

[20] Riad, A., El-Beblawi, M.and Abdel-Azim, G., "Relation between technological properties of rocks and their grindability constant", Bulletin of the faculty Engineering, Assiut Univ., Vol.7 No.1, Jan (1979), pp.177-185.

[21] Riad, A. and Abdel-Azim, G., "Study of the effect of toughness and compressive strength of rocks on the produced surface area and relative growth of surface area", Bulletin of the faculty of Engineering, Assiut Univ, Vol.8 No.1, Jan (1980).

[22] Bzhevsky, and Novick, "The physics of rocks", Mir Publishers Moscow, (1971).

[23] Leib, G., "The design of experiments to find optimal conditions", Mir Publishers Moscow, (1975).

[24] Richard, J.L., and Morris, L.M., "Introduction to mathematical statistics and its application", Sec. Ed, Prentice. Hall International, London, (1986).

[25] Gupta, V.K., "Effect of particulate environment on the grinding kinetics of mixtures of minerals in ball mills", Powder Technol. 375(2020), pp.549-558. 


\section{الطحن التفاضلي للمخاليط الثنائية}

تم طحن عينات ممثلة للحجر الجيري كمادة هشة. والألمنيت كمادة عالية الكثافة (ثقيلة) و الكو ارتز كمادة عالية الصلابة و الصلادة كل على حدة، و على صورة مخاليط ثنائية من الحجر الجيري و الألمنيت والحجر الجيري والكوارتز بنسب خلط مختلفة لخام التغذية في الطاحونة الدوارة ذات الكرات كوسط طاحن. تهدف الدر اسة إلى إظهار تأثثير مكونات خليط التغذية على مواصفات كل مكون للخليط في ناتج الطحن. وقد أظهرت الدراسة أن الكوارتز كمادة عالية الصلابة والصلادة يؤثر بصورة أكبر على طحن الحجر الجيري في خليطهما أكبر من تأثير

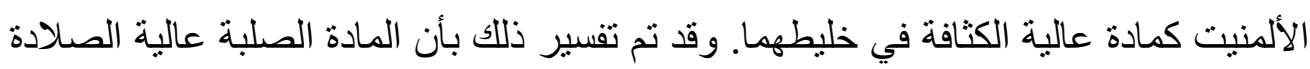
(الكوارتز) أكبر قدرة على نقل طاقة حركة الوسط الطاحن (الكرات) إلى الحجر الجيري من

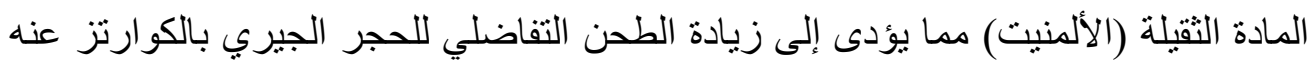




\section{Appendix I}

Table (A.1) Mean particle size analyses of the ground separately limestone, ilmenite, and quartz rocks.

\begin{tabular}{|c|c|c|c|c|c|c|c|}
\hline \multirow{2}{*}{$\begin{array}{l}\text { Particle size } \\
\quad(\mu \mathrm{m})\end{array}$} & \multirow{2}{*}{$\begin{array}{c}\text { Mean } \\
\text { particle } \\
\text { size, } \mu \mathrm{m} . \\
\text { D }\end{array}$} & \multicolumn{2}{|c|}{ Limestone } & \multicolumn{2}{|c|}{ Ilmenite } & \multicolumn{2}{|c|}{ Quartz } \\
\hline & & $\begin{array}{l}\text { wt.\% } \\
\text { ret. }\end{array}$ & $\begin{array}{c}\text { wt. } \% \text { ret. } \\
\times D\end{array}$ & $\begin{array}{l}\text { wt.\% } \\
\text { ret. }\end{array}$ & $\begin{array}{c}\text { wt. } \% \text { ret. } \\
\times \mathrm{D}\end{array}$ & $\begin{array}{l}\text { wt.\% } \\
\text { ret. }\end{array}$ & $\begin{array}{c}\text { wt.\% ret. } \\
\text { ×D }\end{array}$ \\
\hline$-4000+3150$ & 3575 & 0.61 & 2180.75 & 11 & 39325 & 30 & 107250 \\
\hline$-3150+2500$ & 2825 & 2.12 & 5989 & 10.5 & 29662.5 & 22 & 62150 \\
\hline$-2500+2000$ & 2250 & 1.22 & 2745 & 8 & 18000 & 10 & 22500 \\
\hline$-2000+1600$ & 1800 & 0.91 & 1638 & 7 & 12600 & 5 & 9000 \\
\hline$-1600+1000$ & 1300 & 3.03 & 3939 & 5 & 6500 & 2 & 2600 \\
\hline$-1000+630$ & 815 & 6.06 & 4938.9 & 2 & 1630 & 1 & 815 \\
\hline$-630+400$ & 515 & 12.13 & 6246.95 & 2 & 1030 & 1 & 515 \\
\hline$-400+315$ & 357.5 & 7.88 & 2817.1 & 3 & 1072.5 & 1 & 357.5 \\
\hline$-315+200$ & 257.5 & 46.04 & 11855.3 & 6.34 & 1632.55 & 4 & 1030 \\
\hline$-200+160$ & 180 & 1.18 & 212.4 & 8 & 1440 & 4.32 & 777.6 \\
\hline$-160+125$ & 142.5 & 2.12 & 302.1 & 8 & 1140 & 4.9 & 698.25 \\
\hline$-125+100$ & 112.5 & 0.94 & 105.75 & 7 & 787.5 & 5.62 & 632.25 \\
\hline$-100+71$ & 85.5 & 2.12 & 181.26 & 6 & 513 & 6.02 & 514.71 \\
\hline$-71+63$ & 67 & 2 & 134 & 8.5 & 569.5 & 1.57 & 105.19 \\
\hline$-63+0.0$ & 31.5 & 11.64 & 366.66 & 7.66 & 241.29 & 1.57 & 49.46 \\
\hline \multicolumn{2}{|c|}{$\Sigma$} & 100 & 43652.17 & 100 & 116143.84 & 100 & 208994.9 \\
\hline \multicolumn{2}{|c|}{ Median particle size $(\mu \mathrm{m})$} & & 436.52 & & 1161.44 & & 2089.95 \\
\hline \multirow{2}{*}{\multicolumn{2}{|c|}{ Reduction Ratio }} & & 3000 & & 3000 & & 3000 \\
\hline & & & $\begin{array}{l}\overline{436.52} \\
=6.87\end{array}$ & & $\begin{array}{l}\overline{1161.44} \\
=2.58\end{array}$ & & $\begin{aligned} & \overline{2089.95} \\
= & 1.44\end{aligned}$ \\
\hline
\end{tabular}


635

Sherein Ahmed et al., The Preferential Comminution of Binary Mixtures....

Table (A.2) Mean particle size analyses of the ground Limestone - ilmenite mixture at different percentages of ilmenite.

\begin{tabular}{|c|c|c|c|c|c|c|c|c|c|}
\hline \multirow{2}{*}{$\begin{array}{c}\text { Particle } \\
\text { size } \\
(\mu \mathrm{m})\end{array}$} & \multirow{2}{*}{$\begin{array}{l}\text { Mean } \\
\text { particle } \\
\text { size. } \\
\text { D }\end{array}$} & \multicolumn{2}{|c|}{$20 \%$ ilmenite } & \multicolumn{2}{|c|}{ 40\% ilmenite } & \multicolumn{2}{|c|}{$60 \%$ ilmenite } & \multicolumn{2}{|c|}{$80 \%$ ilmenite } \\
\hline & & $\begin{array}{l}\text { wt.\% } \\
\text { ret. }\end{array}$ & $\begin{array}{l}\text { wt.\% ret. } \\
\times \mathrm{D}\end{array}$ & $\begin{array}{l}\text { wt. } \% \\
\text { ret. }\end{array}$ & $\begin{array}{c}\text { wt. \% ret. } \\
\times \mathrm{D}\end{array}$ & $\begin{array}{l}\text { wt.\% } \\
\text { ret. }\end{array}$ & $\begin{array}{l}\text { wt.\% ret. } \\
\times \mathrm{D}\end{array}$ & $\begin{array}{l}\text { wt. \% } \\
\text { ret. }\end{array}$ & $\begin{array}{l}\text { wt.\% ret. } \\
\times \mathrm{D}\end{array}$ \\
\hline- & 3575 & 1.2 & 4290 & 1.11 & 3968.25 & 1.17 & 4182.75 & 0.94 & 3360.5 \\
\hline $3000+3150$ & 2825 & 5.10 & 14407.5 & 8.01 & 22628.25 & 9.32 & 26329 & 15.40 & 43505 \\
\hline- & 2250 & 6.30 & 14175 & 10.90 & 24525 & 14.40 & 32400 & 24.98 & 56205 \\
\hline $3150+2500$ & 1800 & 3.75 & 6750 & 3.78 & 6804 & 8.05 & 14490 & 10.74 & 19332 \\
\hline- & 1300 & 8.69 & 11297 & 14.02 & 18226 & 13.34 & 17342 & 16.20 & 21060 \\
\hline $2500+2000$ & 815 & 9.59 & 7815.85 & 10.68 & 8704.2 & 11.12 & 9062.8 & 8.87 & 7229.05 \\
\hline- & 515 & 6.74 & 3471.1 & 6.68 & 3440.2 & 6.78 & 3491.7 & 4.09 & 2106.35 \\
\hline $2000+1600$ & 357.5 & 2.40 & 858 & 2.01 & 718.6 & 2.32 & 829.4 & 1.40 & 500.5 \\
\hline $\begin{array}{c}- \\
1600+1000 \\
-1000+630 \\
-630+400 \\
-400+315 \\
-315+200 \\
\end{array}$ & 257.5 & 7.80 & 2008.5 & 6.47 & 1666.03 & 5.50 & 1416.25 & 3.28 & 844.6 \\
\hline \multicolumn{2}{|l|}{$\Sigma$} & 51.57 & 65072.95 & 63.66 & 90680.53 & 72.00 & 109543.9 & 85.90 & 154143 \\
\hline$-200+160$ & 180 & 3.35 & 603 & 2.23 & 401.4 & 2.21 & 397.8 & 1.14 & 205.2 \\
\hline$-160+125$ & 142.5 & 2.90 & 413.25 & 2.23 & 317.8 & 1.92 & 373.6 & 0.95 & 135.38 \\
\hline$-125+100$ & 112.5 & 2.64 & 297 & 1.91 & 214.9 & 1.62 & 182.25 & 0.89 & 100.13 \\
\hline$-100+71$ & 85.5 & 5.41 & 462.6 & 3.67 & 313.8 & 2.80 & 239.40 & 1.59 & 135.9 \\
\hline$-71+63$ & 67 & 3.09 & 207.03 & 2.23 & 149.4 & 1.47 & 98.47 & 0.83 & 55.6 \\
\hline$-63+0.0$ & 31.5 & 31.04 & 977.76 & 24.07 & 758.2 & 17.98 & 566.33 & 8.70 & 274.1 \\
\hline \multicolumn{2}{|c|}{$\Sigma$} & 48.43 & 2960.64 & 36.34 & 2155.5 & 28.00 & 1857.85 & 14.1 & 906.31 \\
\hline \multicolumn{2}{|c|}{$\begin{array}{l}\text { Median particle size } \\
\qquad(\mu \mathrm{m})\end{array}$} & & 680.34 & & 928.36 & & 1114.02 & & 1550.49 \\
\hline \multirow{2}{*}{\multicolumn{2}{|c|}{ Reduction ratio }} & & 3000 & & 3000 & & 3000 & & 3000 \\
\hline & & & $\begin{array}{l}680.34 \\
=4.41\end{array}$ & & $\begin{array}{l}928.36 \\
=3.23\end{array}$ & & $\begin{array}{l}1114.02 \\
=2.69\end{array}$ & & $\begin{array}{l}1550.49 \\
=1.93\end{array}$ \\
\hline
\end{tabular}


JES, Assiut University, Faculty of Engineering, Vol. 49, No.5, Sept 2021, pp. 620-636

Table (A.3) Mean particle size analyses of the ground Limestone - quartz mixture at different percentages of quartz.

\begin{tabular}{|c|c|c|c|c|c|c|c|c|c|}
\hline \multirow{2}{*}{$\begin{array}{l}\text { article size } \\
\quad(\mu \mathrm{m})\end{array}$} & \multirow{2}{*}{$\begin{array}{l}\text { Mean } \\
\text { particle } \\
\text { size } \\
\text { D }\end{array}$} & \multicolumn{2}{|c|}{$20 \%$ quartz } & \multicolumn{2}{|c|}{$40 \%$ quartz } & \multicolumn{2}{|c|}{$60 \%$ quartz } & \multicolumn{2}{|c|}{$80 \%$ quartz } \\
\hline & & $\begin{array}{l}\text { wt. } \% \\
\text { ret. }\end{array}$ & $\begin{array}{c}\text { wt.\% } \\
\text { ret } \\
\times \mathrm{D}\end{array}$ & $\begin{array}{l}\text { wt. } \% \\
\text { ret. }\end{array}$ & $\begin{array}{l}\text { wt.\% ret } \\
\times \mathrm{D}\end{array}$ & $\begin{array}{l}\text { wt. } \% \\
\text { ret. }\end{array}$ & $\begin{array}{c}\text { wt. } \% \text { ret } \\
\times \mathrm{D}\end{array}$ & $\begin{array}{l}\text { wt. } \% \\
\text { ret. }\end{array}$ & $\begin{array}{l}\text { wt.\% ret } \\
\quad \times D\end{array}$ \\
\hline - & 3575 & 2.86 & 10224.5 & 4.79 & 17124.25 & 7.73 & 27634.8 & 5.95 & 21271.3 \\
\hline $4000+3150$ & 2825 & 11.90 & 33617.5 & 17.02 & 48081.5 & 18.44 & 52093 & 24.16 & 68252 \\
\hline- & 2250 & 6.19 & 13927.5 & 11.17 & 25132.5 & 10.73 & 24142.5 & 15.62 & 35145 \\
\hline $3150+2500$ & 1800 & 3.33 & 5994 & 6.65 & 11970 & 5.58 & 10044 & 7.06 & 12708 \\
\hline & 1300 & 10.47 & 13611 & 10.10 & 13130 & 9.87 & 12831 & 11.15 & 14495 \\
\hline $2500+2000$ & 815 & 9.99 & 8141.85 & 7.98 & 6503.7 & 8.15 & 6642.3 & 8.18 & 6666.7 \\
\hline & 515 & 6.19 & 3187.85 & 5.06 & 2605.9 & 5.58 & 2873.7 & 6.32 & 3254.8 \\
\hline $2000+1600$ & 357.5 & 2.38 & 850.85 & 1.86 & 664.95 & 2.58 & 922.35 & 2.61 & 933.1 \\
\hline $\begin{array}{c}- \\
1600+1000 \\
-1000+630 \\
-630+400 \\
-400+315 \\
-315+200\end{array}$ & 257.5 & 6.18 & 1591.35 & 5.59 & 1439.43 & 6.43 & 1655.73 & 6.68 & 1720.1 \\
\hline \multicolumn{2}{|l|}{$\Sigma$} & 59.49 & 91146.4 & 70.22 & 126652.23 & 75.09 & 138838.98 & 87.73 & 164446 \\
\hline$-200+160$ & 180 & 2.63 & 473.4 & 2.69 & 484.2 & 2.60 & 468 & 1.49 & 268.2 \\
\hline$-160+125$ & 142.5 & 2.50 & 356.25 & 1.95 & 277.9 & 2.15 & 306.4 & 1.26 & 179.6 \\
\hline$-125+100$ & 112.5 & 2.10 & 236.25 & 1.71 & 192.4 & 1.47 & 165.4 & 0.93 & 104.6 \\
\hline$-100+71$ & 85.5 & 4.34 & 371.07 & 3.42 & 292.4 & 2.89 & 247.1 & 1.71 & 146.21 \\
\hline$-71+63$ & 67 & 3.68 & 246.56 & 1.47 & 98.50 & 1.64 & 109.9 & 0.71 & 47.6 \\
\hline$-63+0.0$ & 31.5 & 25.26 & 795.69 & 18.54 & 584.01 & 14.16 & 446 & 6.17 & 194.4 \\
\hline \multicolumn{2}{|c|}{$\Sigma$} & 40.51 & 2479.22 & 29.78 & 1929.41 & 24.91 & 1742.8 & 12.27 & 940.6 \\
\hline \multicolumn{2}{|c|}{$\begin{array}{l}\text { Median particle size } \\
(\mu \mathrm{m})\end{array}$} & & 936.26 & & 1285.82 & & 1405.82 & & 1653.87 \\
\hline \multicolumn{2}{|c|}{ Reduction ratio } & & $\begin{array}{l}\frac{3000}{936.26} \\
=3.2\end{array}$ & & $\begin{array}{l}\frac{3000}{1285.82} \\
= \\
2.33\end{array}$ & & $\begin{array}{l}\frac{3000}{1405.82} \\
=\begin{array}{l}2.13\end{array}\end{array}$ & & $\begin{array}{l}\frac{3000}{1653.87} \\
=1.81\end{array}$ \\
\hline
\end{tabular}





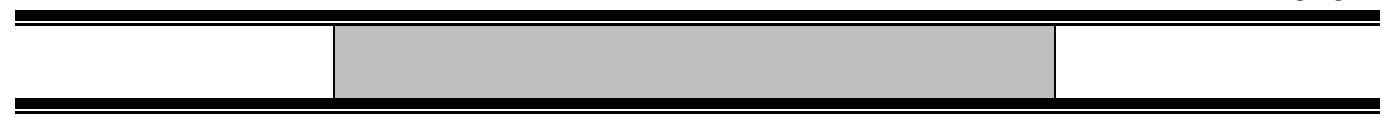





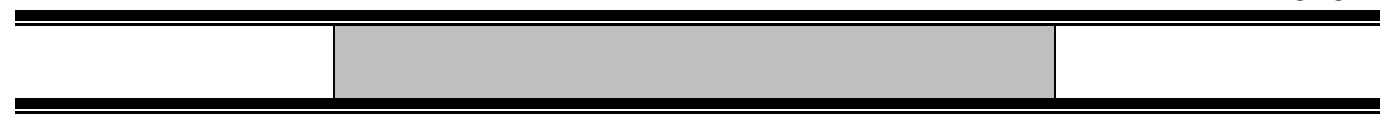

